\title{
UPAYA MENUJU DEMOKRATISASI PENDIDIKAN
}

\author{
Oleh: Teguh Sihono \\ (Staff Pengajar Fakultas Ekonomi, Universitas Negeri Yogyakarta)
}

\begin{abstract}
The new paradigm education providing in order to capable produce results the generation who was came to play the role of nation young society be a live process and stating affair. Education expected will became efficacious medicine for medicine society disease. This importance are there base aspect the thing which necessary renewed that is regulation, professionalism, and management.

Purpose education create the thing which democratic or education democratization, the state was make UU No. 22- 1999 year, UU No. 32-2004 year (Regional autonomy), UU No. 20- 2003 year (Sisdiknas), PP No 19-2005 year (SPN), Permendiknas No. 22, 23, 24 -2006 year (KTSP implementation). Implementation curriculum of KTSP the thing which give the right and freedom, community participation, organizer authority, supporter institution, and stakeholder's, there is as like real effort for creates education democratization in Indonesia. In order that capable the human resources which qualified, and superiority competitiveness.
\end{abstract}

Key ward: democratis, and education

\section{A. Pendahuluan}

Reformasi bidang politik di Indonesia pada penghujung abad ke 20 Masehi, telah membawa perubahan besar pada kebijakan pengembangan sektor pendidikan, yang secara umum tertumpu pada dua paradigma baru yaitu otonomisasi dan demokratisasi. Undang-Undang No. 32 Tahun 2004 tentang Otonomi Daerah telah meletakkan sektor pendidikan sebagai salah satu yang diotonomisasikan bersama sektor pembangunan lain yang berbasis kedaerahan. Otonomisasi sektor pendidikan berusaha mengkondisikan sekolah agar kepala sekolah, guru memiliki tanggung jawab besar dalam peningkatan kualitas proses pembelajaran guna meningkatkan kualitas hasil belajar.

Bersamaan dengan itu, pemerintah juga mengeluarkan Undang-Undang No. 20 Tahun 2003 tentang Sistem Pendidikan Nasional, sebagai pengganti Undang-Undang No 2 tahun 1989. Isu penting dalam Undang-Undang tersebut adalah keterlibatan masyarakat dalam pengembangan 
sektor pendidikan, sebagaimana tersurat pada pasal 9 bahwa masyarakat berhak untuk berperan serta dalam perencanaan, pelaksanaan, pengawasan dan evaluasi program pendidikan. Pasal ini merupakan kelanjutan dari pasal 4 ayat (1) bahwa pendidikan di Indonesia diselenggarakan secara demokratis dan berkeadilan. Demokrasi pendidikan merupakan implikasi dari kebijakan yang mendorong pengelolaan sektor pendidikan di daerah, yang implementasinya di tingkat sekolah.

1. Politik, Ekonomi dan Demokrasi

Perubahan politik yang secara dramatis terjadi di Indonesia telah memposisikan bangsa ini dalam konstalasi yang dilematis dan sangat kompleks. Kondisi semacam ini dilihat dari perspektif pendidikan menunjukkan telah terjadi proses rekayasa yang amat lama, sehingga secara teoritis membuktikan adanya keterkaitan yang erat antara politik, ekonomi dan pendidikan. Tulisan ini akan memaparkan keterkaitan antara demokrasi dan ekonomi, serta bagaimana transformasi pendidikan mesti dilakukan agar mampu mempersiapkan generasi baru yang memasuki alam demokrasi.

Kaitan antara kapitalisme dengan demokrasi telah lama menjadi diskursus dan takkan pernah selesai sampai kapanpun. Tokoh modern Max Weber dan Joseph Schumpeter menegaskan adanya hubungan antara kapitalis dengan demokrasi. Weber dan Schumpeter menyatakan bahwa demokrasi akan tumbuh berkembang dan kokoh sejalan dengan pertumbuhan ekonomi kapitalis. Masyarakat demokrasi merupakan produk ekonomi kapitalis, yang mendorong timbulnya masyarakat madani. Namun Schumpeter menyadari adanya benih konflik yang akan melahirkan ketegangan antara kapitalis dengan demokrasi.

Robert Dahl mengemukakan dalam bukunya "After the Revolution: Authority in Good Society" (1990) suatu fakta yang tidak dapat dibantah lagi. Lembaga modern demokratis hanya hadir dalam masyarakat yang menjamin hak milik pribadi dan ekonomi berorientasi pasar (kapitalis). Seymour Martin Lipset, dalam bukunya Political Man: The Social Bases of Politics (1981) berpendapat bahwa pemilikan pribadi dan ekonomi berorientasi pasar memiliki hubungan dengan demokrasi, secara bersama-sama yang memegang nilai-nilai untuk mendorong pertumbuhan masyarakat.

Milton dan Rose Friedman, tidak saja meyakini adanya keterkaitan antara kebebasan ekonomi dan politik, akan tetapi juga meyakini bahwa keduanya muncul dari sumber yang sama yaitu kemerdekaan individu atas kekuasaan negara. Gabriel Almond, Profesor Emeritus Stanford University, menunjukkan bahwa logika sejarah dan statistik membuktikan hubungan yang 
signifikan antara pertumbuhan demokrasi dengan kapitalis. Hubungan kebebasan ekonomi dengan kebebasan politik tidak selamanya mulus, seperti kritikan Mancur Olsen: Di negara demokrasi hanya terdapat beberapa kelompok warga masyarakat yang memiliki kemampuan lebih, dan kelompok ini senantiasa berusaha memastikan keuntungan bagi mereka sendiri di atas pengorbanan masyarakat luas.

Ekonomi kapitalis yang diterapkan di Indonesia semenjak tahun 1970-an diawali masuknya modal asing dan disertai dengan berbagai kebijakan ekonomi kapitalis, ternyata tidak diikuti dengan kebebasan politik. Ketertutupan sosial, politik, dan ekonomi melahirkan persekongkolan sosial, politik dan ekonomi yang akhirnya menyuburkan jaringan KKN (Korupsi, Kolusi dan Nepotisme) yang luas dan melembaga.

\section{Pendidikan dan kebebasan Politik-Ekonomi}

Dalam membangun masyarakat yang demokratis diperlukan pendidikan, agar warga tidak sekedar mampu membaca dan menulis, serta berhitung. Warga perlu memahami fungsi pemerintah yang demokratis sesuai dengan konstitusi dan faham tentang konsep pasar bebas. Kemampuan warga masyarakat akan dua hal ini akan menentukan derajat rasionalitas keputusan yang diambil. Dalam kaitannya dengan pendidikan, pendidikan ekonomi ditekankan pada upaya memfasilitasi setiap peserta didik dengan pengetahuan dan kemampuan yang diperlukan untuk mengambil keputusan individual dan pengambilan keputusan secara partisipatif.

Pendidikan yang bersifat demokratis harus memiliki tujuan menghasilkan lulusan yang mampu berpartisipasi dalam kehidupan masyarakat dan mampu mempengaruhi pengambilan keputusan kebijakan publik. Dengan kata lain, pendidikan harus mampu menanamkan kesadaran dan membekali pengetahuan akan peran warga dalam masyarakat demokratis.

\section{Paradigma Baru Pendidikan}

Paradigma baru pendidikan, menuntut agar pendidikan mampu melahirkan manusia demokratis yang akan memerankan dirinya sendiri sebagai anak bangsa dalam proses kehidupan bermasyarakat dan bernegara. Ternyata pendidikan yang diharapkan sebagai obat mujarab bagi penyakit masyarakat ternyata sudah terkonstaminasi oleh virus. Orde baru mengkondisikan pendidikan sebagai instrumen melanggengkan kekuasaan Suharto lewat indoktrinasi politik. Sehingga Kepala Sekolah, Guru dan tenaga kependidikan tidak lagi bersinergi secara professional, melainkan bekerja berdasarkan instruksi, petunjuk dan arahan. Sekolah bukan lagi wahana yang 
bersifat demokratis, melainkan merupakan lembaga yang birokratis. Lembaga pendidikan yang anti demokrasi, mustahil akan melahirkan manusia-manusia yang berwatak demokratis. Oleh sebab itu demokratisasi lembaga pendidikan perlu mendapatkan prioritas perhatian. Dengan kata lain reformasi pendidikan yang mendasar atau transformasi pendidikan suatu keharusan yang tidak bisa ditunda lagi.

Ada tiga aspek dasar yang perlu diperbaharui, yaitu regulasi, profesionalitas, dan manajemen. Reformasi tiga aspek ini sangat diperlukan agar dapat menciptakan kondisi sekolah yang memungkinkan peserta didik menjadi dirinya sendiri. Peserta didik dapat menemukan jati dirinya dan bertindak sesuai dengan dirinya sendiri, memenuhi interes dan dapat mengembangkan bakatnya, mampu mengambil keputusan secara rasional untuk kepentingan dirinya sendiri, keluarganya dan masyarakat.

\section{B. Kontribusi Pendidikan Dalam Demokrasi}

Saat ini sebagian masyarakat demokratis diartikan sama dengan masyarakat bebas demonstrasi, yang intinya bebas memaksakan kehendak kelompoknya dengan tekanan kekerasan. Pihak pemerintah karena ketakutan terhadap sorotan dunia internasional, cenderung terbawa arus pemikiran bahwa kebebasan merupakan akar demokrasi yang akan tumbuh dan berkembang secara alami sejalan dengan pertumbuhan masyarakat. Maka pemerintah yang demokratis harus memberikan kebebasan penuh bagi para warga negara untuk menyatakan pendapatnya.

\section{Makna Demokrasi}

Benyamin Barber dalam bukunya yang berjudul Aristocracy of Everyone, menolak pemikiran tersebut dengan menekankan bahwa demokrasi bukanlah bentuk organisasi yang tumbuh secara alami, melainkan tumbuh dan berkembang sebagai hasil usaha keras menggali ide-ide dengan penuh imaginasi. Juga bukan berarti demokrasi, kebijakan pemerintah yang memperhatikan dan memberikan warga yang tidak terdidik dengan hak untuk ikut mengambil keputusan bersama, sebagaimana hak yang diberikan kepada warga terdidik. Menurut Apple dan James A. Beane, "Democracy is the central tenet of our social and political relations. It is, we say, the basis for how we govern ourselves, the concept by which we measure the wisdom and worth of social polities and shifts, the ethical anchor we seek when our political ship seems to drift. And it is the standard we use to measure the political progress of other countries as well as their trade status with our own". 
Demokrasi merupakan gagasan/pandangan hidup yang mengutamakan persamaan hak dan kewajiban serta perlakuan yang sama bagi semua warganegara. Secara absolut dapat dikatakan bahwa kekuatan tertinggi langsung ada di tangan rakyat. Sedangkan secara material demokrasi merupakan corak pemerintahan yang menjamin kemerdekaan dan kesamaan, misalnya kemerdekaan berfikir dan mengemukakan pendapat, berapat dan berkumpul, kemerdekaan mengatur diri sendiri yang dilandasi oleh corak pemerintah.

Demokrasi sejati membutuhkan hukum, peraturan, lembaga yang menegakkannya, dan sikap demokratis. Sikap demokratis di dalamnya terkandung kebesaran hati untuk mengakui kesalahan, kesediaan untuk bekerja sama dalam mencapai tujuan kesejahteraan masyarakat luas, dan mampu mengkombinasikan semangat untuk menegakkan pendiriannya serta kompromi dengan kesadaran bahwa seseorang tidak dapat mewujudkan semua yang diinginkan, dan kombinasi antara kesadaran individu denga kelompok. Secara subtantif berdimensi panjang untuk mendidik warga negara yang baik guna menjamin terwujudnya masyarakat demokratis, pendidikan demokrasi mutlak diperlukan.

Pendidikan demokrasi bertujuan mempersiapkan warga masyarakat berfikir kritis dan bertindak demokratis, melalui aktivitas menanamkan pada generasi baru yang menyadari akan tiga hal. Pertama, demokrasi adalah bentuk kehidupan bermasyarakat yang paling menjamin hak-hak warga negara. Kedua, demokrasi adalah suatu learning process yang tidak dapat begitu saja meniru dari masyarakat lain. Ketiga, kelangsungan demokrasi tergantung pada keberhasilan menstransformasikan nilai-nilai demokrasi (kebebasan, persamaan dan keadilan, serta loyal kepada sistem politik yang bersifat demokratis.

Tujuan pendidikan demokrasi adalah mempersiapkan warga masyarakat berfikir kritis, dan berperilaku demokratis. Persoalan yang muncul: mungkinkan pendidikan demokratis dapat diselenggarakan dalam suasana sekolah yang birokratis, hierarkis-sentralistis dan elitis, seperti sekolah yang ada saat ini? Terselenggara dan keberhasilan pendidikan demokrasi memerlukan reformasi di bidang pendidikan yang berkaitan dengan kebebasan akademik, kebhinnekaan pendidikan, dan perombakan materi pendidikan civics.

\section{Kebebasan Akademik}

Pengaruh dan pengawasan yang bersifat indoktrinasi dari luar sekolah harus diminimasikan, sebaliknya ide school based management, mulai dikembangkan, Sekolah harus memiliki 
kemandirian, memiliki kebebasan otonomi. Kebebasan akademik diperlukan guna mengembangkan prinsip demokrasi di sekolah yang bertumpu pada interaksi dan kerja sama berdasarkan pada sikap saling menghormati dan memperhatikan satu sama lain, berfikir kreatif, menemukan solusi atas masalah yang dihadapi bersama. Sekolah yang demokratis harus mendorong dan memberikan kesempatan semua siswa aktif berpartisipasi dalam pengambilan keputusan, merencanakan kegiatan dan melaksanakan rencana tersebut.

Kebebasan akademik menuntut sekolah tidak dapat dipisahkan dengan aktivitas politik. Karena hubungan politik dengan pendidikan amatlah erat bahkan cenderung bersifat sosial alami. Seperti pernyataan Plato dan Aristoteles: Apapun yang diinginkan suatu negara, harus juga disediakan di sekolah.

\section{Pendidikan Kebhinekaan}

Kebhinekaan masyarakat Indonesia termanifestasikan dalam Bhineka Tunggal Ika, yang di dalamnya termasuk kehidupan pendidikan. Tujuan pendidikan "Ika", namun proses dalam mencapai tujuan bersifat "bhinneka". Kurikulum yang memuat pokok-pokok pembelajaran dapat ditentukan secara nasional, namun penjabaran dan implementasi ditentukan oleh masing-masing satuan pendidikan di daerah yang tergantung kondisi lapangan yang ada, baik menyangkut sosial, budaya, maupun sarana-prasarana pendidikan. Pendidikan kebhinnekaan menghargai dan mengakomodir perbedaan latar belakang siswa yang menyangkut nilai, budaya, sosial, ekonomi, bahkan perbedaan kemampuan. Oleh sebab itu perlu dipertanyakan suatu kebijakan yang bersifat dan berlaku seragam seperti Ujian Nasional (UN) perlu dipertanyakan. Kebijakan yang bersifat nasional akan cenderung melecehkan prinsip-prinsip kebhinekaan yang adil.

\section{Civics}

Di era orde baru, sekolah berupaya menciptakan bentuk perilaku politik tertentu, dengan mengimplementasikan pendidikan kurikulum kewarganegaraan yang mendasarkan pada disiplin yang kaku dan bersifat indoktrinatif. Berbagai kegiatan ekstra kurikuler yang dilakukan diharapkan mendukung tercapainya terbentuknya perilaku politik tertentu. Alam pendidikan politik yang indoktrinatif, siswa mengikuti kegiatan seremonial dalam bentuk upacara yang penuh rasa keterpaksaan. Pendidikan kewarganegaraan penuh dengan doktrin dan informasi yang tidak diperlukan siswa. Maka awal proses reformasi, mutlak diperlukan reformasi pendidikan 
kewarganegaraan. Prinsip indoktrinasi harus diminimalkan, karena memang tidak mungkin dihilangkan.

\section{Tantangan}

Memperbaharui pendidikan kewarganegaraan dalam jangka pendek akan menghadapi tantangan dari sisa-sisa orde baru yang masih memiliki kekuatan di dunia pendidikan. Wujud nyata tantangan yang menghambat pendidikan di Indonesia adalah keinginan dan perilaku penguasa orde reformasi untuk mempertahankan sistem sentralisasi dan birokrasi yang berlebihan dalam dunia pendidikan. Fenomena ini memang tidak hanya muncul di Indonesia, akan tetapi juga muncul di hampir semua negara bekas komunis di Eropa Timur, yang sedang mereformasi pendidikannya.

\section{Sekolah Demokratis}

Memasuki abad ke- 21, isu perbaikan pendidikan di Indonesia mencuat ke permukaan, disuarakan oleh semua departemen terkait sebagai otoritas pengelola jalur pendidikan, dan juga para praktisi dan policy maker dalam pembangunan sektor pembinaan sumber daya manusia. Bersamaan dengan hal ini, di awal abad ke- 21, prestasi pendidikan di Indonesia tertinggal jauh di bawah negara Asia lainnya, seperti Singapura, Malaysia, dan Jepang. Jika dilihat dari indeks sumber daya manusia yang salah satu indikatornya sektor pendidikan, posisi Indonesia mengalami penurunan dari tahun ke tahun. Padahal Indonesia kini menjadi bagian masyarakat dunia yang tidak bisa dihindari. Hal ini akan memposisikan Indonesia terpuruk dalam meraih pasar dan peluang kerja di era global. Oleh sebab itu, penyiapan sumber daya manusia yang berkualitas, kompetitif dan memiliki berbagai keunggulan komparatif, sudah menjadi keharusan perhatian sektor pendidikan.

Ada beberapa pemikiran pengembangan konteks pendidikan ke depan dalam memasuki abad ke-21 yang membawa berbagai problem ekonomi, sosial dan politik. Pemikiran tersebut adalah sebagai berikut.

1. Perkembangan IPTEK (IImu Pengetahuan dan Teknologi) serta informasi membuat bahan ajar yang harus disampaikan dalam pendidikan menjadi sangat banyak, dikhawatirkan akan membawa stagnasi pengembangan ilmu dan peradaban khususnya pada level pendidikan tinggi. Oleh sebab itu struktur program pendidikan tinggi harus memberikan jaminan pemberian reward dan insentif yang memadai terhadap pengembangan ilmu dan teknologi 
2. Perkembangan teknologi yang terus-menerus dapat terjadi dengan akselerasi tinggi yang akan mempengaruhi perkembangan ekonomi melalui industri dan jasa. Oleh sebab itu pendidikan harus mampu menjembatani antara sektor kerja dengan kemjuan ilmu dan teknologi.

3. Terjadinya perubahan demografis membawa implikasi pada persebaran penduduk, di mana negara maju angka kelahiran rendah dan di negara berkembang angka kelahiran tinggi. Di negara maju akan berusaha meningkatkan pendapatannya, namun mengalami kekurangan angka angkatan kerja, dan tergantung pada negara berkembang untuk memenuhi tenaga kerja. Oleh sebab itu negara berkembang harus merancang outcome pendidikannya untuk memenuhi pasar global tenaga kerja.

4. Setiap negara akan saling tergantung pada sektor ekonomi, politik, dan IPTEK. Oleh sebab itu pendidikan harus mampu membuka cakrawala global tersebut dan mampu mengarahkan sikap multikulturalisme, ketika memasuki pasar tenaga kerja.

5. Kemajuan IPTEK mendorong perkembangan sektor ekonomi ke arah pasar global dan membawa implikasi terbentuknya masyarakat baru. Maka Pendidikan harus mampu mendesain masyarakat baru tersebut, menjadi masyarakat humanis, menjaga lingkungan dan ekosistem, anti drug/obat, dan senantiasa hidup sehat.

Pandangan dan analisis di atas setidaknya merefleksikan beberapa faktor penting yang mendasari pentingnya reformasi pendidikan, yaitu: kegagalan pendidikan waktu lalu dan mempersiapkan SDM dalam menghadapi pasar global.

Pengembangan sekolah menuju model sekolah demokratis ini relevan untuk dilakukan, dengan berbagai argumentasi, yang secara garis besar dapat dikategorikan menjadi dua tipologi sekolah abad ke-21, dan model pembelajaran yang sesuai. Menurut Lyn Hass (1994) menjelaskan bahwa sekolah-sekolah sekarang harus dapat memenuhi beberapa kualifikasi ideal, yaitu:

1. Pendidikan untuk semua; semua siswa mendapatkan perlakuan sama untuk mencapai kompetensi keilmuan, basis skill dan ketrampilan yang ingin dicapai oleh kurikulum.

2. Memberikan skill dan ketrampilan yang sesuai dengan kemajuan teknologi yang menjadi tuntutan pasar.

3. Penekanan pada kerja sama; memberikan pengalaman pada siswa dalam bekerja sama dengan yang lain, melalui penugasan kelompok dalam pembelajaran. 
4. Pengembangan kecerdasan ganda; memberikan kesempatan kepada siswa untuk mengembangkan multiple intelligence mereka, dengan memberikan peluang mengembangkan skill dan ketrampilan yang beragam.

5. Integrasi program dengan pengabdian pada masyarakat, agar mereka memiliki kepekaan sosial. Bergulirnya UU No. 22 tahun 1999 adalah perubahan radikal dalam otoritas pengembangan pendidikan, yang semula berada di pemerintah pusat (Depdiknas), kini terdelegasi ke pemerintah daerah. Perubahan radikal tersebut mendapatkan penguatan dengan UU No. 20 tahun 2003 (lihat pendahuluan) bahwa pendidikan diselenggarakan secara demokratis dan berkeadilan serta menjunjung tinggi hak asasi manusia, nilai keagamaan, nilai kultural, dan kemajemukan bangsa (pasal 4 ayat 1). Dalam pasal 9 dinyatakan bahwa masyarakat berhak berperan serta dalam perencanaan, pelaksanaan, pengawasan dan evaluasi program pendidikan. Dua poin penting di sini adalah pendidikan diselenggarakan secara demokratis dan evaluasi keberhasilan sekolah.

Penyelenggaraan secara demokrasi; keterlibatan masyarakat, otoritas pengelola, dan institusi pendukung lebih besar dari pada pemerintah pusat, bahkan bentuk keterlibatan masyarakat dalam komite sekolah dan dewan pendidikan daerah. Komite sekolah berhak ikut serta dalam merumuskan perencanaan pendidikan baik secara makro maupun kebijakan restrukturisasi dalam gagasan kurikulum.

Pemerintah diberi kewenangan oleh undang-undang sebagaimana dicatumkan dalam pasal 10 bahwa pemerintah dan pemerintah daerah berhak mengarahkan, membimbing, membantu dan mengawasi penyelenggaraan pendidikan sesuai dengan peraturan perundang-undangan yang berlaku. Pada pasal 11 ayat (1) dan (2) dinyatakan bahwa pemerintah dan pemerintah daerah wajib memberikan layanan dan kemudahan, serta menjamin terselenggaranya pendidikan yang bermutu bagi setiap warga negara tanpa diskriminasi. Pemerintah dan pemerintah daerah wajib menyediakan dana guna terselenggaranya pendidikan bagi setiap warga negara yang berusia tujuh sampai lima belas tahun.

\section{Demokratisasi Kurikulum}

Kurikulum adalah seperangkat rencana dan pengaturan mengenai tujuan, isi, dan bahan pelajaran serta cara yang digunakan sebagai pedoman penyelenggaraan kegiatan pembelajaran untuk mencapai tujuan pendidikan tertentu. 
Dalam menyelenggarakan sekolah ada suatu pertanyaan yang cukup mendasar yaitu: "Siswa mau dibawa ke mana oleh sekolah? Dan Siapa yang berhak menentukan arah dan kebijakan sekolah?". Semangat demokratis dalam penyelenggaraan sekolah akan terinspirasi bahwa publik sekolah memiliki hak yang sangat kuat dan besar dalam menentukan arah kebijakan kurikulum sekolah. Kuat dan besarnya hak sekolah dalam menetapkan arah kebijakan kurikulum, bisa dikatakan sama dengan pemerintah.

Kurikulum merupakan inti dari sebuah sekolah, karena menawarkan pada publik dengan dukungan guru dan tenaga kependidikan serta sarana sumber belajar yang memadai. Diskursus kurikulum memang masih berjalan terus, apakah kurikulum itu hanya bermakna Course of Line/GBPP, atau mencakup seluruh pengalaman yang diberikan kepada siswa dalam proses pendidikannya. Dalam konteks ini Ronald C. Doll menjelaskan bahwa kurikulum sudah tidak lagi bermakna sebagai rangkaian bahan dan urutan pelajaran yang akan dipelajari siswa. Akan tetapi seluruh pengalaman yang ditawarkan pada siswa di bawah arahan dan bimbingan sekolah. Pengalaman yang diperoleh siswa dari program yang ditawarkan sekolah cukup variatif, tidak terbatas pembelajaran dalam kelas saja, melainkan juga di lapangan tempat siswa bermain, di kantin bahkan di bus sekolah. Semuanya mempengaruhi perubahan dan memberikan kontribusi pengembangan siswa.

Kurikulum memiliki beberapa karakteristik yaitu: Sebagai suatu substansi, sebagai suatu sistem, dan merupakan suatu konsep dinamis (Sukmadinata)

1. Kurikulum sebagai suatu substansi; kurikulum sebuah rencana kegiatan belajar siswa di sekolah, yang mencakup: rumusan tujuan, bahan ajar, proses kegiatan pembelajaran, jadwal, dan evaluasi hasil belajar. Kurikulum ini merupakan konsep yang telah disusun oleh para ahli dan disetujui oleh pengambil kebijakan pendidikan serta masyarakat sebagai user/pemakai.

2. Kurikulum sebagai sebuah sistem; kurikulum merupakan rangkaian konsep tentang berbagai kegiatan pembelajaran yang masing-masing kegiatan mempunyai keterkaitan secara koheren dengan yang lainnya, bahkan kurikulum itu sendiri memiliki keterkaitan dengan semua unsur dalam sistem pendidikan secara keseluruhan.

3. Kurikulum merupakan sebuah konsep dinamis; Kurikulum merupakan konsep yang terbuka dengan berbagai gagasan perubahan dan penyesuaian dengan tuntutan pasar atau idealisme pengembangan peradaban umat manusia. 
Menurut Allan A. Glattohom, ada tiga variabel penting dalam pengelolaan dan pengembangan sekolah, dan menjadi bagian integral dari hidden curriculum yaitu: organisasi, sistem sosial, dan budaya.

Variabel budaya mengisyaratkan adanya kejelasan rumusan tujuan sekolah yang harus dipahami oleh semua pihak, pengelolaan administrasi memiliki ekspektasi yang tinggi terhadap guru dan sebaliknya, pengelola administrasi dan guru memiliki ekspektasi yang baik terhadap siswa, pemberian hadiah terhadap mereka yang mencapai prestasi terbaik, atau hukuman secara fair serta konsisten kepada siswa.

Demokratisasi Pengembangan Kurikulum

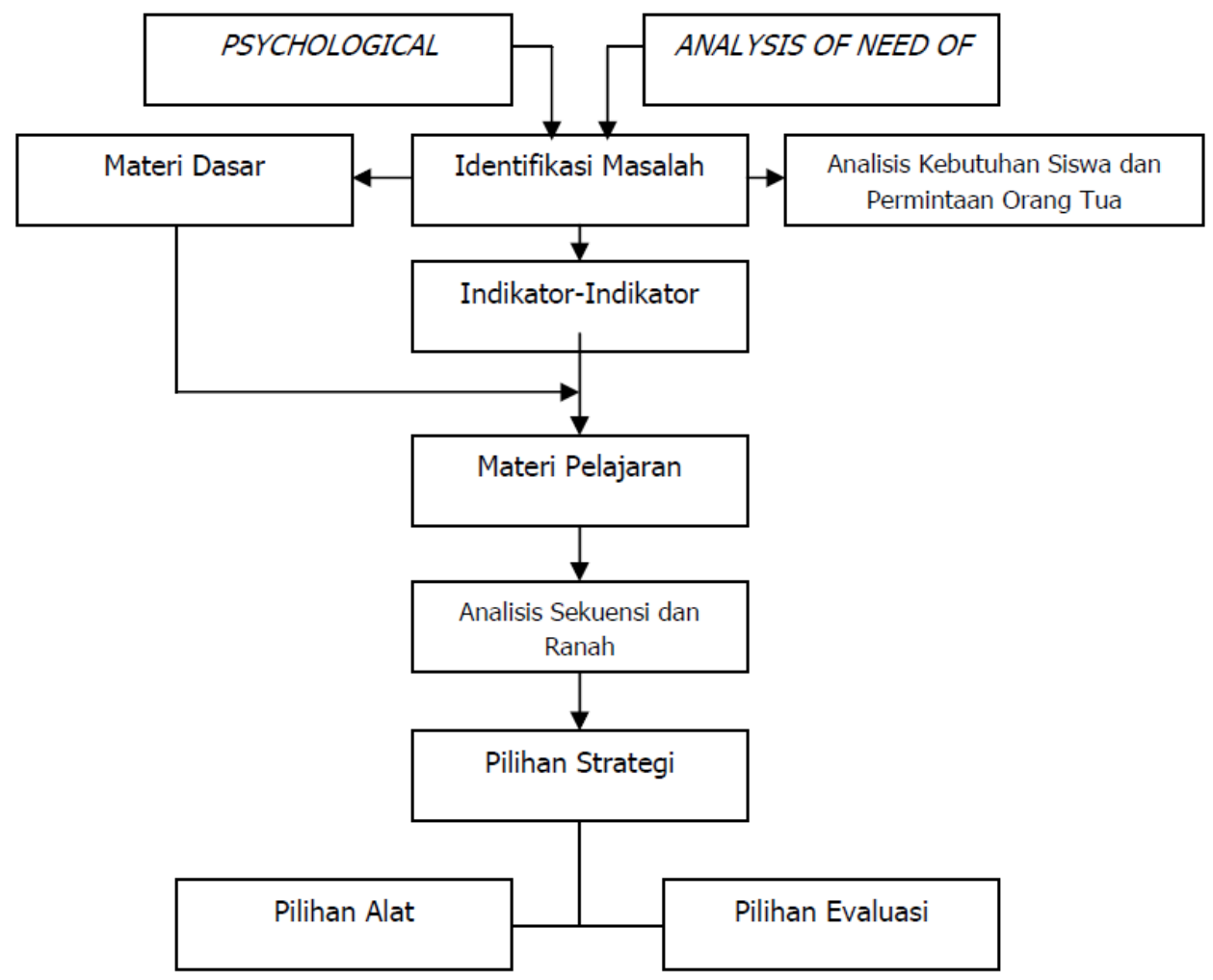

Gambar 1. Model Perumusan Kurikulum Yang Relevan (Adaptasi Dari Westneyer) 
Demokratisasi Pengembangan Kurikulum.

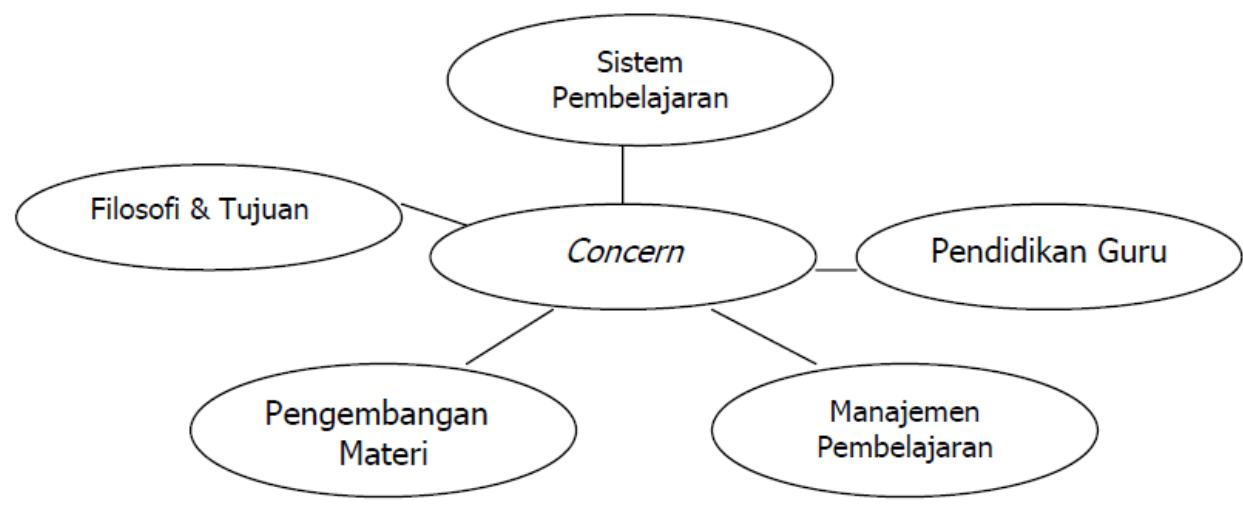

Gambar 2. Bidang-Bidang Yang Mempengaruhi Kurikulum (Adaptasi Wiles-Bondi)

Guna merealisasikan keberhasilan pendidikan, dengan mewujudkan demokrati- sasi pendidikan, pemerintah melalui kurikulum telah berusaha untuk melaksanakan KBK (Kurikulum Berbasis Kompetensi) dan dilanjutkan dengan Kurikulum Tingkat Satuan Pendidikan (KTSP). Memang harus diakui bahwa ada keengganan dari pemerintah pusat untuk memberikan otonomi yang sesungguhnya kepada daerah. Pasalnya, apabila semuanya diserahkan kepada daerah kewenangan pusat berangsur-angsur berkurang dan akhirnya bisa habis. (hal yang sangat tidak diinginkan). Keengganan yang sama berlaku juga di bidang pendidikan. Pemerintah seolah-olah telah memberikan otonomi sepenuhnya antara lain dengan kebijakan Kurikulum Berbasis Kompetensi (KBK) yang diikuti dengan Kurikulum Satuan Tingkat Pendidikan (KTSP). Semua itu (teorinya) ditujukan agar sekolah menjadi otonom. Tapi pemerintah pusat hanya memberi kewenangan semu, karena belum mau berubah dengan mengevaluasi kebijakannya yang antiotonomi, seperti ujian nasional yang standarnya setiap tahun selalu dinaikkan dan masih banyak kecurangan. 


\section{E. Kurikulum Tingkat Satuan Pendidikan (KTSP) Sebagai Upaya Menuju- Demokratisasi Pendidikan.}

\section{Pengertian KTSP}

KTSP adalah kurikulum operasional yang disusun oleh dan dilaksanakan di masing-masing satuan pendidikan. KTSP terdiri dari tujuan pendidikan tingkat satuan pendidikan, struktur dan muatan kurikulum tingkat satuan pendidikan, kalender pendidikan, dan silabus.

Sebagai kebijakan yang menekankan pada kompetensi, KTSP (Kurikulum Tingkat Satuan Pendidikan) memberikan peluang kepada peserta didik agar menjadi seorang yang kompeten/ahli dalam bidang tertentu. Sehingga kelak, jika peserta didik sudah lulus/tamat, tidak mengalami kesulitan dalam mencari atau memeroleh bahkan menyiptakan lapangan pekerjaan bagi dirinya sendiri.

2. Kurikulum Berbasis Kompetensi (KBK) dan KTSP (Kurikulum Tingkat Satuan Pendidikan)

Pengertian pendidikan dan kehidupan telah menyatu dalam kerangka filosofi, bahwa: proses dalam pendidikan tidak lain adalah proses bagi manusia dalam mengarungi samudera kehidupan, dan sebaliknya. Sementara makna filosofi pendidikan adalah proses bagaimana manusia mengenali diri dengan segenap potensi yang dimilikinya dan memahami apa yang tengah dihadapinya dalam realitas kehidupan. Pengertian ini dapat bermakna bahwa: pendidikan merupakan strategi untuk menghadapi masalah kehidupan manusia yang kian hari semakin rumit/pelik. Seperti gagasan Paulo Freire (1921-1997) tentang "Filosofi Pendidikan Kritis" (Critical Education) sebagai counter terhadap model pendidikan bank (Banking Education), sebagai model pendidikan yang mampu menghadapi persoalan kehidupan manusia.

Dalam konteks sistem pendidikan nasional (Sisdiknas), usaha mendekontruksi dasar-dasar filosofi pendidikan yang menghambat kreativitas dan daya kritis peserta didik, mulai tampak setelah reformasi tahun 1998 yang lalu. Yaitu dengan lahirnya Kurikulum Berbasis Kompetensi (KBK) pada tahun 2004. Kurikulum ini menganjurkan setiap pendidik agar memberikan kesempatan pada peserta didik untuk pro aktif dalam proses pembelajaran (belajar-mengajar). Di samping hal tersebut, seiring dengan perubahan sistem pemerintahan lewat Undang-Undang Otonomi Daerah No. 32 tahun 2004, Sisdiknas yang semula bersifat sentralistik berubah menjadi desentralistik dengan UU No. 20 tahun 2003. 
Menjawab amanah otonomi pendidikan dari Undang-Undang Sisdiknas tersebut, Departemen Pendidikan Nasional (Depdiknas) telah mengeluarkan kebijakan berupa Kurikulum Tingkat Satuan Pendidikan (KTSP) pada tahun 2006 yang lalu. KTSP ini merupakan kurikulum operasional yang disusun dan dilaksanakan di masing-masing satuan pendidikan. Dengan demikian setiap satuan pendidikan dasar dan menengah dituntut menyusun dan mengembangkan kurikulum sendiri sesuai dengan kebutuhan, karakteristik satuan pendidikan, potensi daerah, dan kondisi sosial budaya masyarakat setempat. KTSP juga merupakan usaha untuk mempertegas pelaksanaan Kurikulum Berbasis Kompetensi (KBK). Artinya, kurikulum ini tetap memberikan tekanan pada pengembangan kompetensi peserta didik. Selama ini masih ada anggapan yang salah, bahwa: KTSP ini menggantikan KBK, seakan-akan kurikulum berubah tanpa alasan yang jelas. Padahal sebenarnya KBK dan KTSP itu bukan sebuah perubahan, melainkan proses yang belum selesai. KTSP merupakan penyempurnaan dan tetap berdasarkan pendekatan KBK, yang sangat menganjurkan kompetensi anak didik untuk memecahkan permasalahan kehidupan di masa depan mereka kelak.

Perubahan kurikulum pada dasarnya suatu kewajaran, yang biasa dilakukan setiap 10 tahun sekali. Misalnya tahun 1984, tahun 1994, tahun 2004 yang sudah disiapkan semenjak tahun 2001, namun belum memiliki produk hukum yang memayunginya. Baru tahun 2005 lahirlah payung hukum, berupa Peraturan Pemerintah (PP) No. 19 tentang Standar Nasional Pendidikan. Kemudian, Depdiknas menyempurnakannya dalam bentuk KTSP pada tahun 2006.

\section{Pengembangan KTSP}

KTSP dikembangkan sesuai dengan relevansinya oleh setiap kelompok atau satuan pendidikan di bawah koordinasi dan supervisi dinas pendidikan atau kantor Departemen Agama Kabupaten/Kota untuk pendidikan dasar dan provinsi untuk pendidikan menengah. Pengembangan KTSP mengacu pada SI dan SKL dan berpedoman pada panduan penyusunan kurikulum yang disusun oleh BSNP, serta memperhatikan pertimbangan komite sekolah/madrasah. Penyusunan KTSP untuk pendidikan khusus dikoordinasi dan disupervisi oleh dinas pendidikan provinsi, dan berpedoman pada SI dan SKL serta panduan penyusunan kurikulum oleh BSNP.

KTSP dikembangkan berdasarkan prinsip-prinsip sebagai berikut.

a. Berpusat pada potensi, perkembangan, kebutuhan, dan kepentingan peserta didik dan lingkungannya. 
Kurikulum dikembangkan berdasarkan prinsip bahwa peserta didik memiliki posisi sentral untuk mengembangkan kompetensinya agar menjadi manusia yang beriman dan bertakwa kepada Tuhan Yang Maha Esa, berakhlak mulia, sehat, berilmu, cakap, kreatif, mandiri dan menjadi warga negara yang demokratis serta bertanggung jawab. Untuk mendukung pencapaian tujuan tersebut pengembangan kompetensi peserta didik disesuaikan dengan potensi, perkembangan, kebutuhan, dan kepentingan peserta didik serta tuntutan lingkungan. Memiliki posisi sentral berarti kegiatan pembelajaran berpusat pada peserta didik.

b. Beragam dan terpadu

Kurikulum dikembangkan dengan memperhatikan keragaman karakteristik peserta didik, kondisi daerah, jenjang dan jenis pendidikan, serta menghargai dan tidak diskriminatif terhadap perbedaan agama, suku, budaya, adat istiadat, status sosial ekonomi, dan jender. Kurikulum meliputi substansi komponen muatan wajib kurikulum, muatan lokal, dan pengembangan diri secara terpadu, serta disusun dalam keterkaitan dan kesinambungan yang bermakna dan tepat antarsubstansi.

C. Tanggap terhadap perkembangan ilmu pengetahuan, teknologi dan seni

Kurikulum dikembangkan atas dasar kesadaran bahwa ilmu pengetahuan, teknologi dan seni yang berkembang secara dinamis. Oleh karena itu, semangat dan isi kurikulum memberikan pengalaman belajar peserta didik untuk mengikuti dan memanfaatkan perkembangan ilmu pengetahuan, teknologi, dan seni.

\section{d. Relevan dengan kebutuhan kehidupan}

Pengembangan kurikulum dilakukan dengan melibatkan pemangku kepentingan (stakeholders) untuk menjamin relevansi pendidikan dengan kebutuhan kehidupan, termasuk di dalamnya kehidupan kemasyarakatan, dunia usaha dan dunia kerja. Oleh karena itu, pengembangan keterampilan pribadi, keterampilan berpikir, keterampilan sosial, keterampilan akademik, dan keterampilan vokasional merupakan keniscayaan.

e. Menyeluruh dan berkesinambungan

Substansi kurikulum mencakup keseluruhan dimensi kompetensi, bidang kajian keilmuan dan mata pelajaran yang direncanakan dan disajikan secara berkesinambungan antarsemua jenjang pendidikan. 


\section{f. Belajar sepanjang hayat}

Kurikulum diarahkan kepada proses pengembangan, pembudayaan, dan pemberdayaan peserta didik yang berlangsung sepanjang hayat. Kurikulum mencerminkan keterkaitan antara unsur-unsur pendidikan formal, nonformal, dan informal dengan memperhatikan kondisi dan tuntutan lingkungan yang selalu berkembang serta arah pengembangan manusia seutuhnya.

g. Seimbang antara kepentingan nasional dan kepentingan daerah

Kurikulum dikembangkan dengan memperhatikan kepentingan nasional dan kepentingan daerah untuk membangun kehidupan bermasyarakat, berbangsa, dan bernegara. Kepentingan nasional dan kepentingan daerah harus saling mengisi dan memberdayakan sejalan dengan motto Bhineka Tunggal Ika dalam kerangka Negara Kesatuan Republik Indonesia (NKRI).

h. Demokratisasi dan Otonomisasi Pendidikan

Seperti telah dipaparkan di muka demokratisasi pendidikan memberikan pendelegasian wewenang kepada daerah dan sekolah untuk mengelola dan menentukan arah pendidikan di tingkat sekolah, serta memberikan perlakuan sama kepada semua siswa/masyarakat. Manakala demokratisasi ini diikuti dengan otonomi pendidikan, maka daerah dan sekolah mempunyai kekuasaan dalam menentukan arah tindakannya sendiri. Pada hakikatnya Esensi dalam pendidikan akan tertuang pada kurikulum yang dipergunakan oleh tingkat sekolah masingmasing. Sehingga perwujudan demokratisasi dan otonomi pendidikan akan teraktualisasi dalam penyusunan dan penggunaan/ pelaksanaan kurikulum.

Sebagai suatu kebijakan yang menekankan pada kompetensi, KTSP memberikan peluang kepada peserta didik untuk menjadi seorang yang kompeten (ahli). Sehingga kelak, setelah peserta didik lulus/tamat dari sekolah, ia tidak akan kesulitan dalam mencari, memeroleh, dan menyiptakan lapangan pekerjaan untuk dirinya sendiri. Saat ini yang diperlukan di lapangan adalah kompetensi, ketrampilan-ketrampilan yang memang dibutuhkan dalam menjalani kehidupan. Karena hal itulah, salah satu target KTSP adalah memecahkan masalah ketenagakerjaan (pengangguran) yang sejauh ini masih menjadi masalah utama bangsa Indonesia.

Kompetensi yang dimaksud dalam KTSP adalah kompetensi yang disesuaikan dengan potensi daerah masing-masing. Pihak sekolah dengan para stake holder-nya diberi wewenang seluas-luasnya untuk mengembangkan kurikulum sekolah yang bisa menghantarkan peserta 
didik mereka menjadi seorang ahli/kompeten dalam bidang tertentu, sesuai dengan potensi yang ada di daerah masing-masing. Bila tempat /daerah penyelenggaraan pendidikan dekat dengan pantai, maka kurikulum yang diutamakan adalah bidang perikanan dan kelautan. Bila daerah penyelenggara pendidikan dekat dengan pertambangan, maka kurikulum diutamakan adalah persoalan pertambangan.

Kebijakan yang lebih akomodatif (mengakomodir) ide kreatif para stake-holder pendidikan tersebut, berangkat dari kesadaran bahwa Indonesia merupakan bangsa yang memiliki beraneka ragam budaya dan potensi daerah yang besar dan bisa terus dikembangkan. Adapun pihak yang lebih mengetahui tentang potensi daerah adalah para stake holder pendidikan di daerah masing-masing. Namun dalam perjalanannya, toh ada saja sebagian pihak yang masih keberatan terhadap program KTSP. Mereka memahami untuk menuju KTSP dibutuhkan sarana dan prasarana seperti: laboratorium, perpustakaan, dan lain sebagainya, dan pihak sekolah bukan berarti menolak KTSP. Yang lebih utama dari KTSP yaitu komitmen dalam memberikan kontribusi berharga bagi peserta didik. Karena KTSP bersifat demokratis yang otomatis disesuaikan dengan kemampuan masing-masing sekolah. Jikalau belum siap, tidak perlu memaksakan diri.

Menurut Prof Dr. Mungin Eddy Wibowo, standar utama yang dijadikan dasar KTSP bukan standar sarana dan prasarana, melainkan standar isi (SI) dan standar kompetensi lulusan (SKL), seperti yang telah diatur oleh Peraturan Menteri Pendidikan Nasional No. 24 tahun 2006 tentang Pelaksanaan Peraturan Menteri Pendidikan Nasional No. 22 tahun 2006 dan N0. 23 tahun 2006. Bahkan beleid ini memermudah pihak sekolah untuk mengadopsi atau mengadaptasi model kurikulum tingkat satuan pendidikan dasar dan menengah yang disusun oleh BNSP. Jika suatu sekolah belum mampu membuat kurikulum sendiri, dapat mengadopsi kurikulum sekolah lainnya yang sudah mengacu pada KTSP.

Jika sekolah telah melaksanakan uji coba kurikulum 2004 secara menyeluruh, dapat menerapkan secara menyeluruh Permendiknas No 22 tahun 2006 dan No. 23 tahun 2006 mulai tahun ajaran baru 2008/2009 ini. Namun perlu kita cermati pada pasal 2 ayat 3 Permendiknas No. 24 itu tertulis: "kata dapat", bukan harus. Ini berarti, bila sekolah belum mampu, bisa menerapkan KTSP secara bertahap. Bertolak dari beberapa hal di atas, rasa optimis dari seluruh stake holder pendidikan dan warga negara Indonesia umumnya, diharapkan dapat membantu terwujudnya cita-cita pendidikan Indonesia yang bermartabat, dan mampu mengantarkan 
generasi bangsa menjadi manusia yang kompetitif di tataran internasional. Dan kemunculan KTSP merupakan konsekuensi logis dari perkembangan ilmu pengetahuan, teknologi, dan tuntutan zaman. Ini tentunya sesuai dengan sabda Rasullullah Muhammad SAW, " Hendaknya kita mengajar anak-anak kita sesuai dengan zamannya" 


\section{i. KTSP Sebagai Upaya Menuju Demokratisasi Pendidikan}

Diberlakukannya Kurikulum Berbasis Kompetensi (KBK) pada tahun 2004, kemudian sisempurnakan dengan KTSP pada tahun 2006, maka secara politis ini merupakan otonomi pendidikan di tingkat sekolah. KTSP ini merupakan kurikulum operasional yang disusun dan dilaksanakan di masing-masing satuan pendidikan. Dengan demikian setiap satuan pendidikan dasar dan menengah dituntut menyusun dan mengembangkan kurikulum sendiri sesuai dengan kebutuhan, karakteristik satuan pendidikan, potensi daerah, dan kondisi sosial budaya masyarakat setempat. KTSP juga merupakan usaha untuk mempertegas pelaksanaan KBK. Artinya, kurikulum ini tetap memberikan tekanan pada pengembangan kompetensi anak didik.

Perubahan radikal dalam otoritas pengembangan pendidikan, yang semula berada di pemerintah pusat (Depdiknas), kini terdelegasi ke pemerintah daerah (UU No. 22 tahun 1999). Perubahan tersebut mendapatkan penguatan dengan UU No. 20 tahun 2003 bahwa pendidikan diselenggarakan secara demokratis dan berkeadilan serta menjunjung tinggi hak asasi manusia, nilai keagamaan, nilai kultural, dan kemajemukan bangsa (pasal 4 ayat 1). Dalam pasal 9 dinyatakan bahwa masyarakat berhak berperan serta dalam perencanaan, pelaksanaan, pengawasan dan evaluasi program pendidikan. Dua poin penting di sini adalah pendidikan diselenggarakan secara demokratis dan evaluasi keberhasilan sekolah.

Penyelenggaraan secara demokrasi; keterlibatan masyarakat, otoritas pengelola, dan institusi pendukung lebih besar dari pada pemerintah pusat, bahkan bentuk keterlibatan masyarakat dalam komite sekolah dan dewan pendidikan daerah. Komite sekolah berhak ikut serta dalam merumuskan perencanaan pendidikan baik secara makro maupun kebijakan restrukturisasi dalam gagasan kurikulum.

Pemerintah diberi kewenangan oleh undang-undang sebagaimana dicantumkan dalam pasal 10 bahwa pemerintah dan pemerintah daerah berhak mengarahkan, membimbing, membantu dan mengawasi penyelenggaraan pendidikan sesuai dengan peraturan perundang-undangan yang berlaku. Pada pasal 11 ayat (1) dan (2) dinyatakan bahwa pemerintah dan pemerintah daerah wajib memberikan layanan dan kemudahan, serta menjamin terselenggaranya pendidikan yang bermutu bagi setiap warga negara tanpa diskriminasi. Pemerintah dan pemerintah daerah wajib mengusahakan tersedianya dana guna terselenggaranya pendidikan bagi setiap warga negara yang berusia tujuh sampai lima belas tahun. 
Dalam penyusunan dan pengembangan kurikulum tingkat satuan pendidikan (KTSP) selalu mendasarkan pada prinsip-prinsip diantaranya :

a. berpusat pada potensi, perkembangan, kebutuhan, dan kepentingan peserta didik dan lingkungannya.

b. beragam dan terpadu

c. tanggap terhadap perkembangan ilmu pengetahuan, teknologi dan seni

d. relevan dengan kebutuhan kehidupan

e. seimbang antara kepentingan nasional dan kepentingan daerah

Mengingat esensi pendidikan irtu terletak pada kurikulum, sementara dalam pengembangan kurikulum tingkat satuan pendidikan (KTSP) mendasarkan pada beberapa prinsip yang menunjukkan adanya unsur-unsur demokrasi, hal ini sebagai bukti bahwa adanya kemerdekaan dalam menyelenggarakan pendidikan. Artinya terdapat jaminan kemerdekaan bagi satuan pendidikan (sekolah) untuk berfikir, mengemukakan pendapat, berapat dan berkelompok dalam mengambil keputusan, serta dalam mengatur dirinya sendiri. Bergulirnya Undang-Undang No 22 tahun 1999, UU No. 32 tahun 2004 (Otonomi daerah), UU No. 20 tahun 2003 (Sisdiknas) sebgai pengganti UU No 2 tahun 1989, Peraturan Pemerintah No. 19 tahun 2005 (Standar Pendidikan Nasional), Permendiknas No. 22, No. 23, No 24 tahun 2006 (Pelaksanaan KTSP), secara simultan merupakan perwujudan upaya menuju demokratisasi pendidikan guna menggapai tujuan pendidikan nasional.

\section{F. Kesimpulan}

Perubahan besar pada kebijakan pengembangan di bidang pendidikan di Indonesia semenjak terjadi reformasi di bidang politik, yang secara umum tertumpu pada otonomisasi dan demokratisasi. Politik, ekonomi dan demokrasi mempunyai keterkaitan yang cukup erat, yang saling berpengaruh yang muncul dari sumber kemerdekaan individu atas kekuasaan Negara. Dalam membangun masyarakat yang demokratis diperlukan pendidikan, agar masyarakat tidak sekedar mampu membaca dan menulis serta berhitung, akan tetapi mampu memahami fungsi pemerintah yang demokratis sesuai dengan konstitusi dan pasar bebas.

Paradigma baru pendidikan menuntut agar pendidikan mampu melahirkan manusia demokratis yang akan memerankan dirinya sendiri sebagai anak bangsa dalam proses kehidupan 
bermasyarakat dan bernegara. Kontribusi pendidikan dalam demokrasi mempersiapkan warga masyarakat berfikir kritis dan bertindak demokratis, yaitu menjamin hak-hak warga negara, proses pembelajaran, dan mentransfor- masikan nilai-nilai demokrasi. Penyelenggaraan sekolah secara demokratis sebagai upaya untuk mengejar ketinggalan Indonesia dalam bidang pendidikan terhadap negara Asia lainnya (Malaysia, Singapura, Jepang) dengan melibatkan masyarakat, komite sekolah, dan dewan pendidikan, serta stakeholders.

Kurikulum adalah inti dari sebuah sekolah, apabila terjadi demokratisasi pengembangan kurikulum seperti diberlakukannya KTSP semenjak tahun 2006, ini membuktikan suatu demokratisasi pendidikan di tingkat sekolah telah terjadi. Kurikulum Tingkat Satuan Pendidikan (KTSP) terdiri dari tujuan pendidikan tingkat satuan pendidikan, struktur dan muatan kurikulum satuan pendidikan, kalender akademik dan silabus yang disusun dan dilaksanakan pada setiap tingkat satuan pendidikan. Yang semuanya ini mentransformasikan otonomi dan demokratisasi pendidikan pada tingkat sekolah/satuan pendidikan.

Pelaksanaan kurikulum tingkat satuan pendidikan (KTSP) yang memberikan hak dan kebebasan, keterlibatan masyarakat, otoritas pengelola, institusi pendukung, dan pihak yang berkepentingan, tidak lain sebagai upaya untuk mewujudkan demokratisasi pendidikan di Indonesia. 


\section{Daftar Pustaka}

Alisjahbana, Armida S. 2000. "Otonomi Daerah dan Desentralisasi Pendidikan”, Bandung : Fakultas Ekonomi, Universitas Padjadjaran.

Almand Gabriel A. (1991), Capitalism and Democracy, Jurnal Of Political Science and Politics.

Apple W.Michael and Jame A. Beane. (1999). Democratic Schools: Lessons From The Chalk Face. Buckingham, Open University Press.

Apple W. Michael. (1986) Ideology, Reproduction and Education, edited by Philliph G. Altbach and Gail P. Kelly. Chicagp. ILL, The University of Chicago Press.

Budiono, 1998. "Dampak Krisis Ekonomi dan Moneter Terhadap Pendidikan", Jakarta:

Pusat Penelitian Sains dan Teknologi, Lembaga Penelitian Universitas

Indonesia. Jakarta

Burki, Shahid j. 1999. Guillermo E. Perry dan William E. Dillinger, "Beyond the Center: Decentralizing the State, Washington DC: World Bank.

Dahl Robert, John (1990). After The Revolution: Authority in a Good Society. New Haaven, Yale University Press.

Ki Supriyoko. 1999."Rekonstruksi Landasan Pendidikan Nasional”, dalam Masyarakat

Versus Negara: Paradigma Baru Membatasi Dominasi Negara, Jakarta:

Penerbit KOMPAS.

Martin, Lipset, Seymor (1981). Political Man: The Social Bases of Politics. Expanded Edition. Baltimore, John Hopkins University Press.

Milton and Rose Friedman. (1962). Capitalism and Freedom. Chicago, University of Chicago Press.

Patrinos, Harry A. dan David L. Ariasingam.1997. "Decentralization of Education:

Demand-Side Financing", Washington DC: World Bank.

Republik Indonesia, UU No. 32 Tahun 2004 tentang Pemerintahan Daerah, Oktober -, UU No. 33 tahun 2004 tentang Perimbangan Keuangan Antara Pemerintah Pusat dan Pemerintahan Daerah, Oktober

Schumpeter Joseph. (1946). Capitalsm, Socialism and Democracy. NewYork, Harper

Suryadi, Karim.1999. "Demokratisasi Pendidikan Demokrasi", dalam Masyarakat Versus Negara: Paradigma Baru Membatasi Dominasi Negara, Jakarta: Penerbit KOMPA. by www.unggulcenter.co.cc

Zamroni. 2007. Pendidikan Dan Demokrasi Dalam Transisi (Prakondisi Menuju Era Global). Jakarta, PSAP Muhammadiyah.

Zamroni. (2001). Pendidikan Untuk Demokrasi. Yogyakarta, Bigraf Publishing. 